https://doi.org/10.15407/ujpe63.10.916

I.P. ZHARKOV, A.N. IVASHCHENKO, V.V. SAFRONOV, A.V. SELIVANOV, A.G. SOLONETSKY

Institute of Physics, Nat. Acad. of Sci. of Ukraine (46, Nauky Ave., Kyiv 03028, Ukraine)

\title{
EXTENSION OF TEMPERATURE CONTROL INTERVAL IN LIQUID-FLOW HELIUM CRYOSTATS
}

A method and a device are proposed, which allow the interval of temperature control in liquidflow cryostats to be to extended from 2 to $520 \mathrm{~K}$.

Ke ywords: liquid-flow cryostat, temperature control interval, method, device.

\section{Introduction}

Experimental physicists are always interested in changes of the physical properties of studied materials within a temperature interval from the lowest attainable to the critical values. One of the most important directions of such researches is based on magneticelectric and spectral methods. An auxiliary equipment in those studies includes specialized cryostats of both the continuous gas-flow $[1,2]$ and liquid-flow (the so-called bath-flow cryostats) $[3,4]$ types. The gasflow cryostats, owing to their constructive features, can provide optical studies in the temperature interval from 2 to $500 \mathrm{~K}$ and higher for non-optical modifications [5] or for special solutions [6]. The liquid-flow cryostats can be used in this case, only if it has a welded (rigid) construction.

The cryostat systems of the liquid-flow UTRECS type (the abbreviation of Unified Thermally Regulated Cryostat System) [7], which are manufactured at the Institute of Physics of the National Academy of Sciences of Ukraine, are widely known in the world due to their high parameters and exploitation advantages in comparison with their Western analogs, as well as a possibility of repairing because of their

(C) I.P. ZHARKOV, A.N. IVASHCHENKO,

V.V. SAFRONOV, A.V. SELIVANOV,

A.G. SOLONETSKY, 2018

916 soldered construction. Unfortunately, just because of the last circumstance and the presence of adhesive optical entries, the upper temperature limit of spectral researches was confined by the melting temperature of the adhesive basis of the entries that are mounted at the thermally regulated cryostat chamber, namely, $+57^{\circ} \mathrm{C}$ or $330 \mathrm{~K}$.

\section{Experimental Part}

In order to extend the interval of thermal regulation in liquid-flow helium cryostats of the UTRECS type toward higher temperatures and to avoid a substantial reconstruction of the cryostat design, we have studied the temperatures in the region, where the glued optical entries are mounted at the thermostating chamber. In particular, we imitated the heating of an experimental specimen up to $500 \mathrm{~K}$ in various modes:

- air was pumped out from the chamber down to $10^{-2} \mathrm{Hg} \mathrm{mm}$, by using a vacuum pump;

- without pumping out air from the chamber;

- with a direct thermal bridge mounted between the cryostat nitrogen screen at room temperature and the thermostating chamber without pumping out air from the chamber;

- with a direct thermal bridge mounted between the cryostat nitrogen screen at room temperature and

ISSN 2071-0194. Ukr. J. Phys. 2018. Vol. 63, No. 10 


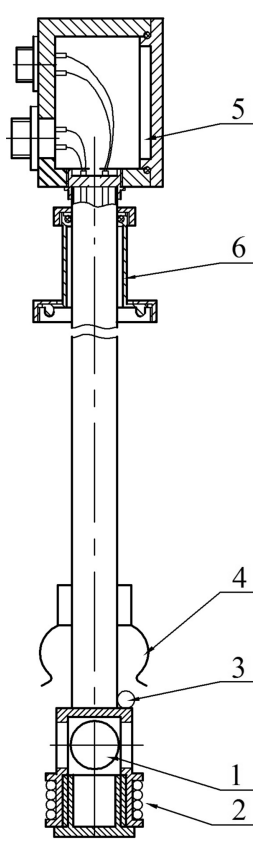

Fig. 1. Insert assembly into a cryostat: the specimen holder with an electric heater. Specimen (1), electric heater (2), temperature sensor (3), alligning gear (4), switcing box (5), extension tube $(6)$

the thermostating chamber with air pumped out from the chamber;

- with a direct thermal bridge mounted between the cryostat nitrogen screen at a temperature of $77 \mathrm{~K}$ and the thermostating chamber without pumping out air from the chamber;

- with a direct thermal bridge mounted between the cryostat nitrogen screen at a temperature of $77 \mathrm{~K}$ and the thermostating chamber with air pumped out from the chamber.

The specimen was heated with the help of a heater mounted on a specimen holder (see Fig. 1). The latter was made from a nichrome wire $0.12 \mathrm{~mm}$ in diameter with a total resistance of $65 \Omega$. A dc voltage varied from 12 to $24 \mathrm{~V}$ was applied to the holder. The thermal bridge was created by means of two copper stripes with the following parameters: a thickness of $1 \mathrm{~mm}$, a width of $15 \mathrm{~mm}$, and a length of $100 \mathrm{~mm}$. The stripes were fixed at the nitrogen screen, and the cryostat thermostating chamber with the help of stainless clamps.

The temperature was measured by means of two categorized silicon temperature sensors WAD-

ISSN 2071-0194. Ukr. J. Phys. 2018. Vol. 63, No. 10

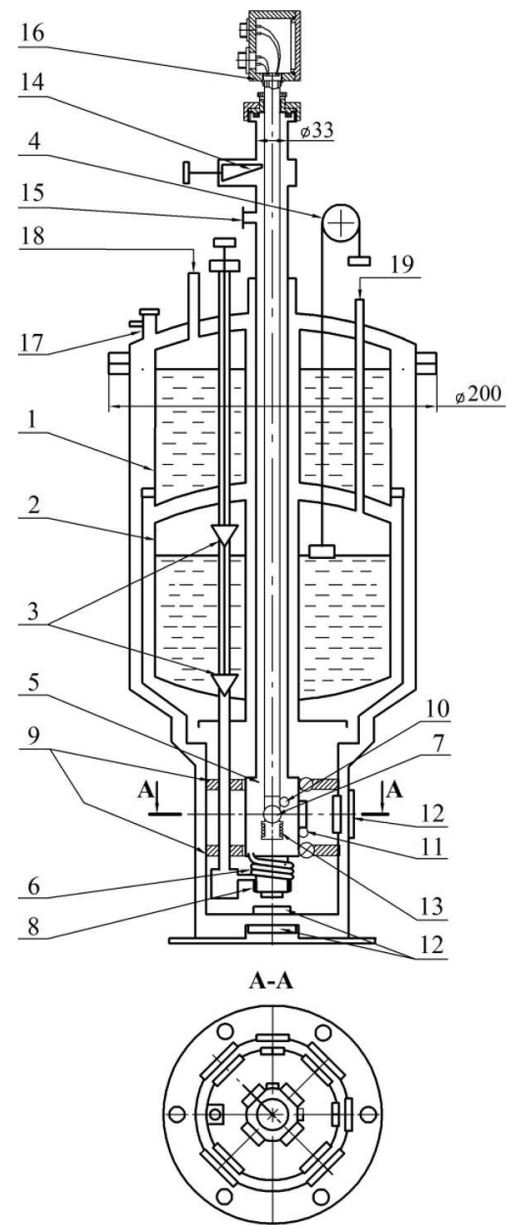

Fig. 2. Design of helium cryostat with a thermal bridge and the insert assembly: nitrogen can (1), helium can (2), needle valves (3), level indicator (4), thermostating chamber (5), heat exchanger (6), specimen (7), electric heater (8), assembling heat bridge $(9)$, temperature sensor $(10)$, overheating protection sensor (11), windows (12), electric heater (13), sluice gate (14), vapor pumping port (15), specimen holder with heater (16), vacuum valve (17), nitrogen filling (18), helium filling (19)

305. One of them was mounted near the heater, at the site of experimental specimen location; the other at the thermostating chamber frame near the entry window. The schematic diagram of the thermal bridge and the arrangement of the specimen holder with the heater in the cryostat are shown in Fig. 2.

\section{Results and Their Discussion}

The results of experimental studies are quoted in Table. The presented data testify that the direct ther- 
Temperature behavior at the experimental specimen and the window entries of the thermostating chamber at various operation modes

\begin{tabular}{|c|c|c|c|c|}
\hline $\begin{array}{l}\text { Operation } \\
\text { mode }\end{array}$ & $\begin{array}{l}\text { Constructive } \\
\text { features }\end{array}$ & $\begin{array}{c}\text { Nitrogen screen } \\
\text { state }\end{array}$ & $\begin{array}{c}\text { Specimen } \\
\text { temperature, } \mathrm{K}\end{array}$ & $\begin{array}{c}\text { Chamber } \\
\text { temperature, } \mathrm{K}\end{array}$ \\
\hline $\begin{array}{l}\text { Atmosphere in the } \\
\text { thermostating chamber } \\
\text { Vacuum } \\
\text { Atmosphere in the } \\
\text { thermostating chamber } \\
\text { Vacuum } \\
\text { Atmosphere in the } \\
\text { thermostating chamber } \\
\text { Vacuum } \\
\text { Atmosphere in the } \\
\text { thermostating chamber } \\
\text { Vacuum } \\
\text { Vacuum }\end{array}$ & $\begin{array}{l}\text { No thermal bridge } \\
- \\
\text { No thermal bridge } \\
- \\
\text { With thermal bridge } \\
- \\
- \\
- \\
-\end{array}$ & $\begin{array}{l}\text { Room temperature } \\
\text { Same } \\
\text { Cooled with liquid nitrogen } \\
\text { Same } \\
\text { Room temperature } \\
\text { - } \\
\text { Cooled with liquid nitrogen } \\
\text { Same } \\
\text { " }\end{array}$ & $\begin{array}{l}410 \\
430 \\
473 \\
473 \\
\\
473 \\
473 \\
523\end{array}$ & $\begin{array}{l}328 \\
330 \\
332 \\
331 \\
\\
296 \\
283 \\
326\end{array}$ \\
\hline
\end{tabular}

mal bridge between the cold nitrogen screen of cryostat and the thermostating chamber makes it possible to elevate the upper temperature limit of spectral researches in liquid-flow cryostats of the UTRECS type without changing their construction. Instead, the specimen holder in the thermostating chamber should be heated to $500 \mathrm{~K}$, and air should be pumped out from this chamber to the forevacuum pressure.

\section{Conclusion}

The upper temperature limit for spectral studies in the liquid-flow UTRECS cryostats can be elevated to $520 \mathrm{~K}$ without their reconstruction. Instead, the specimen holder in a thermostating chamber should be heated to $500 \mathrm{~K}$ and the forevacuum conditions should be created in this chamber.

1. https://www.janis.com/Products/productsoverview/SuperTranContinuousFlowCryostatSystems/ST-100_OpticalCryostat.aspx.

2. https://www.janis.com/Products/productsoverview/SuperTranContinuousFlowCryostatSystems/ST-500MicroscopyCryostat.aspx.

3. https://www.oxford-instruments.com/products/cryogenicenvironments/optical-cryostats-for-spectroscopy/nitrogencryostats-77k/nitrogen-cryostat-77k-sample-in-exchangegas-optis.
4. http://www.cryovac.de/index.php/cryostats/konti-itcryostats/11-cryogenenic-systems/73-konti-it-spectro-he.

5. https://www.janis.com/Products/productsoverview/SuperTranContinuousFlowCryostatSystems/ST-200_NonOpticalCryostat.aspx.

6. I.P. Zharkov, V.B. Podolich, V.V. Safronov. Thermoregulation system for optical microscopy in a temperature interval of 40-800 K. Prib. Tekhn. Eksp. No. 5, 1 (2005) (in Russian).

7. I.P. Zharkov, V.M. Ermakov, V.V. Safronov, A.G. Chmul. Universal thermoregulated cryostat system. In Proceedings of the 1st Ukrainian Scientific Conference on Semiconductor Physics UNKN-1 (Odessa, September 10-14, 2002), Vol. 2, p. 279 (in Russian).

Received 14.03.18.

Translated from Ukrainian by O.I. Voitenko

І.П. Жарков, О.М. Іващенко,

В.В. Сафронов, О.В. Селіванов, А.Г. Солонецъкий

РОЗШИРЕННЯ ОБЛАСТІ

ТЕРМОРЕГУЛЮВАННЯ ГЕЛІЄВИХ

РІДИННО-ПРОТІЧНИХ КРІОСТАТІВ

$\mathrm{P}$ е $з$ ю м е

3 метою забезпечення більших можливостей у дослідженні фізичних властивостей різних речовин запропоновано спосіб та пристрій для розширення області терморегулювання досліджуваних об'єктів в рідинно-протічних кріостатах від 2 до 520 К включно. 